\title{
Поиск консолидирующего сакрального пространства этнокультурной идентичности в городе индивидуализированной массы
}

\author{
${ }^{1}$ Бобков А.И., ${ }^{2}$ Бобков А.А. \\ ${ }^{1}$ Восточно-Сибирский институт МВД России, \\ Россия, 664074 г. Иркутск, ул. Лермонтова, д.110 \\ ${ }^{2}$ Иркутский государственный университет, \\ Россия, 664003 г. Иркутск, ул. К. Маркса, д.1 \\ E-mail: iab71@inbox.ru; alesha.bobkov@inbox.ru
}

\begin{abstract}
Аннотация. Представлено философское осмысление столкновения пространства, консолидирующего массу секулярного характера, и пространства сакральной конъюнкции этнокультурного сообщества в условиях индивидуализированного общества. Показаны тактики разрушения неномадическим сообществом индивидуализированной идентичности пространств репрезентации этнокультурной субъектности. Поставлена проблема самоактуализации практик сакрализации городского пространства в контексте противодействия археоавангарда сконструированной этноархаике.
\end{abstract}

Ключевые слова: сконструированная этноархаика, этнокультурное сообщество, индивидуализированное общество, русофобия, социальная конъюнкция, дезинтеграция, неономад, коллективное иррациональное, рационализация пространства.

Для цитирования: Бобков А.И., Бобков А.А. 2021. Поиск консолидирующего сакрального пространства этнокультурной идентичности в городе индивидуализированной массы. NOMOTHETIKA: Философия. Социология. Право 46 (3): 598-601. DOI: 10.52575/2712-746X2021-46-3-598-601

\section{Search for a Consolidating Sacred Space of Ethnocultural Identity in the City of Individualized Mass}

\author{
${ }^{1}$ Alexander I. Bobkov, ${ }^{2}$ Alexey A. Bobkov \\ ${ }^{1}$ East Siberian Institute of the Ministry of Internal Affairs of Russia, \\ 110 Lermontov St, Irkutsk, 664074, Russia \\ ${ }^{2}$ Irkutsk State University, \\ ${ }^{1}$ K. Marx St, Irkutsk, 664003, Russia \\ E-mail: iab71@inbox.ru; alesha.bobkov@ inbox.ru
}

\begin{abstract}
The article presents a philosophical understanding of the collision of the space of the secular nature consolidating the mass and the space of the sacred conjunction of the ethnocultural community in the conditions of an individualized society. The tactics of destruction by a non-nomadic community of the individualized identity of the spaces of representation of ethnocultural subjectivity are shown. The problem of self-actualization of the practices of sacralization of urban space in the context of countering the archaeo-avant-garde to the constructed ethno-archaic is posed.
\end{abstract}

Key words: constructed ethnoarchaics, ethnocultural community, individualized society, russophobia, social conjunction, disintegration, neonomad, collective irrational, rationalization of space. 
For citation: Bobkov A.I., Bobkov A.A. 2021. The Search for a Consolidating Sacred Space of Ethnocultural Identity in the City of the Individualized Mass. NOMOTHETIKA: Philosophy. Sociology. Law series, 46 (3): 598-601 (in Russian). DOI: 10.52575/2712-746X-2021-46-3-598-601

Социальная консолидация или конъюнкция являются такими же закономерными социальными процессами, как и социальная дифференциация или дизъюнкция. В связи с этим необходимо обозначить в социальном пространстве, которое, согласно П.А. Сорокину, значительно отличается от пространства географического, зоны социальной конъюнкции и зоны социальной дизьюнкции. При этом следует отметить, что зоны таких процессов будут обозначены с позиции разных идеологий или социокультурных парадигм поразному.

Наряду с этим важно осознавать и тот факт, что эти пространства могут возникать и исчезать там, где их никто не ждет или, наоборот, кто-либо символически фиксирует их наличие. Скажем, пространство площадей для политических мероприятий или пространства храмов, культурных заведений или образовательных учреждений традиционно полагаются одновременно пространствами консолидации и дифференциации. Общее смысловое определение для них - это пространство зарождения сообщества.

Наиболее конфликтным пространством в контексте социальной консолидации и дифференциации выступает пространство социального обмана или рынка. Его же можно назвать пространством преступной толпы. Сегодня оно совмещается с пространством зрелищ как вторым пространством социальной дизъюнкции с иллюзией конъюнкции. Таким пространством выступают наряду с рынком торгово-развлекательный центр. Но и в них можно найти процессы истинной социальной конъюнкции, если поискать более пристально, хотя для этого необходимо поставить цель дифференциации между среднестатистическим субъектом человека-массы и интеллектуалом, обладающим зрелой этнокультурной идентичностью и осознанной консолидацией, проводящим конъюнктивные процессы там, где, казалось бы, социальная дизъюнкция одержала верх.

С другой стороны, необходимо также помнить и об иных процессах, идущих в городах мира. К ним следует отнести процессы глобальной дизьюнкции, они же - процессы текучей современности или создания индивидуализированного общества с его недопущением иной идентичности, кроме индивидуальной, а следовательно, с недопущением никакого иного сообщества, кроме толпо-элитарного. Здесь же в целях конспирации создается сконструированная этноархаика как иллюзия наличия этнокультурного сообщества в пространстве города.

В противоположность данному процессу необходимо найти пространства, где осуществляется подлинная консолидация этнокультурного сообщества с репрезентацией этнической субъектности. Выявление символики ее наличия ведет к тому, что у человека утрачивается кризисное сознание социального одиночества, вечного социального конфликта и невозможности высказывания собственных мыслей с целью обретения единомыслия.

Конечно, если их можно зафиксировать географически, то это означает, что гражданское сообщество города наиболее зрело и обозначает себя как признающее социальную полисубъектность или полисубъектную социальность. Однако в условиях стремления к мегаполисным образцам и синкретизму такое удается немногим городам. К тому же глобализация задает более жесткий образец рассмотрения социальной консолидации в пространстве города, а именно неономадической стоянки, и не более того. Как полагал 
3. Бауман, в сегодняшнем городе одни смотрят «как жизнь проходит мимо», а другие устремляются вслед за уходящими инвесторами и инвестициями в сторону новых стоянок. Исчезновение социальных субъектов в условиях тотальной объективации и биологизации социального бытия есть наиболее мощная мифологема, превращающая социальное пространство тотальной дизъюнкции. К сожалению, сегодня человек больше обладает навыками отделения, чем объединения. Причина такого качества двойственна. С одной стороны, в мегаполисе исчезает человекоразмерная среда, ее, вслед за Ф. Ницше, можно назвать средой сверхчеловека, средой переоценки ценностей, вечного возвращения, средой воли к власти, средой возвращения к самобытности. Она же, по П.А. Сорокину, может быть названа средой «таинственной энергии любви».

С другой стороны, «взбесившейся обезьяне с манией величия» необходимо пространство, вмещающее ее. Постав, овладевающий социальным бытием, уничтожает пространство, где можно это бытие созерцать, слушать его шепот и интегрироваться в него (М. Хайдеггер). Как говорил в фильме «Брат» герой Гофман: «Город - это злая сила. Сильный приезжает - становится слабым. Город забирает силу. Вот и ты пропал...». Потеря идентичности является одной из печальных практик современного города, если уповать на то, что его суть сильно изменилась в результате «восстания масс» (Х. Ортегаи-Гассет).

Массы космополитичны, они хотят только одного, чтобы в пространстве города исчезла «не-масса», народ. Ее проникновение в пространства самобытности через символы технического превосходства научной картины мира над религиозной или философской картинами замещает символы консолидации самобытных сообществ в пространстве города. Примечательно, что политическая элита, вышедшая из массы, стремится как можно быстрее убрать любые символы национальной консолидации тех сообществ, которые эти города создали или наследовали и развили. Например, в городах Европы мигрантские сообщества скупают католические храмы с целью учреждения в них мечетей, а власти закрывают глаза на то, что возрастающая национальная консолидация титульных национальных сообществ как ответ на вызовы современности требует символической фиксации. Неономадические стоянки гораздо выгоднее самобытных острогов, «думающих» о будущих поколениях. Сегодня в городе все меньше пайдеи и все больше устремленности к ограблению будущего. Ограблению, снижающему духовность и творческое инакомыслие. Сегодня город научает большему отделению от самобытных этнокультурных сообществ, нежели их созиданию. Мифологема того, что мы, владеющие гаджетами, более умны, чем наши предки, отстоявшие страну от католико-протестантской экспансии, вмещается в символическое пространство города гораздо быстрее, чем возврат к духовным практикам, позволяющим обрести то, что «не меняет мильон по рублю» (В.С. Высоцкий).

Что же сегодня может служить указанием на то, что «матрица русофобии» (В.П. Бабинцев, В.П. Римский) отсутствует в городском пространстве, что индивидуальность вполне осознала, что без коллективной интеграции с собственным народом ее мышление не самобытно и не креативно? Следует отметить, что таких пространств уже нет. Есть пространства, еще совмещающие соборные практики партикуляристкого универсализма и западного универсализма, разрушающего самобытность через стирание границ. К таким пространствам в городе относится пространство университета. Здесь идет нешуточная схватка между наукой как частью самобытной культуры, основанной на философском самоутверждении проблемы человеческого бытия, наукой, озадаченной потерей мышления, и наукой внекультурного универсалистского постава, стремящегося к замене мышления обслуживанием умных роботов. 
Если говорить проще, то необходимо очень пристально отслеживать возможность принесения в жертву того, что разъединяет. К такой проклятой части относится мифологема справедливости рынка, репрезентирующая себя в рекламном слогане с превалированием латиницы над кириллицей. Она же демонстрирует возможности удержания массы в клиповом сознании, она же говорит о легкости быть человеком через идею комфорта отсутствия мышления. И мало кто понимает то, что Divide et impera создано было теми, кто хотел власти синкретического комфорта над властью самобытного мышления. Сакральное пространство русского города еще нуждается в осмыслении.

Конфликт интересов: о потенциальном конфликте интересов не сообщалось.

Conflict of interest: no potential conflict of interest related to this article was reported.

\section{ИНФОРМАЦИЯ ОБ АВТОРАХ}

Бобков Александр Иванович, кандидат философских наук, доцент, профессор кафедры философии и социальногуманитарных дисциплин ВосточноСибирского института МВД России, г. Иркутск, Россия

Бобков Алексей Александрович, магистрант 2-го курса специальности «Государственно-муниципальное управление» Иркутского государственного университета, г. Иркутск, Россия

\section{INFORMATION ABOUT THE AUTHORS}

Alexander I. Bobkov candidate of Philosophical Sciences, Associate Professor, Professor of the Department of Philosophy and Social and Humanitarian Disciplines of the East Siberian Institute of the Ministry of Internal Affairs of Russia, Irkutsk, Russia

Alexey A. Bobkov, 2nd-year Master's student of the specialty "State and Municipal Management" of Irkutsk State University, Irkutsk, Russia 